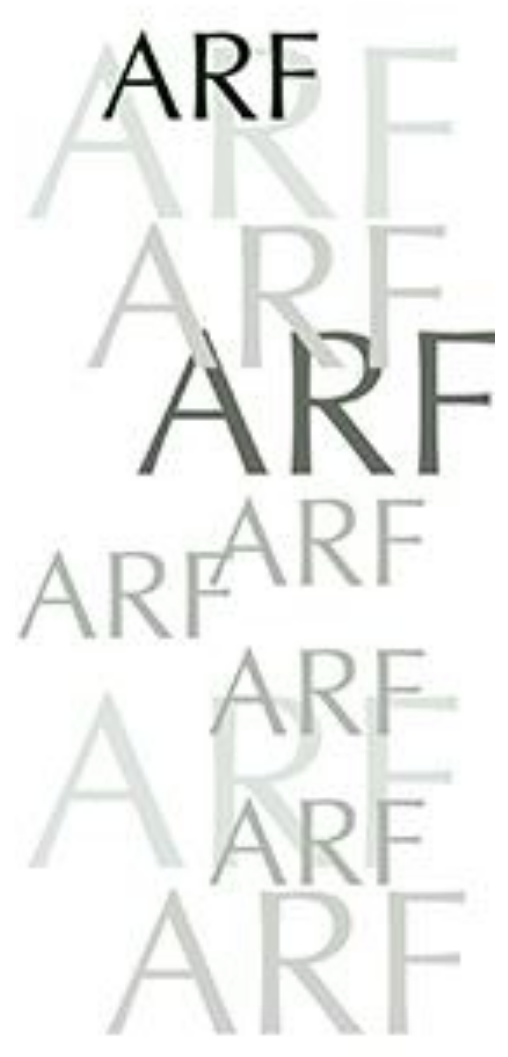

\title{
Symbolic Geographies, Nordic Inspirations and Baltic Identities
}

\author{
Finnish Influence on the Development of Post-war Modernist \\ Architecture in Lithuania during the State Socialist Period
}

\author{
Marija Drèmaitè \\ Vilnius University \\ marija.dremaite@gmail.com
}

\begin{abstract}
'In Finland we really felt architecture,' Lithuanian architect Vytautas Čekanauskas used to say when recalling his first study trip to Finland in 1959. The influence of Nordic architecture is often emphasised when discussing Baltic (Estonian, Latvian and Lithuanian) design in the State Socialist period. When new residential districts in the 1960s were built among the trees in established pine forests, as happened in Āgenskalna Priedes in Riga, Mustamäe in Tallinn, and Lazdynai in Vilnius, Tapiola in Helsinki was most often cited as a source of inspiration. Indeed, as opportunities for tourist travel and foreign exchange programmes increased in the late 1950s, the Soviet Architects' Association began to organize professional delegations that included several representatives from each of the Baltic Republics, dispatched on fact-finding missions to Finland. But why did Finland become so important in the development of Baltic post-war modernism (19591969)? In this paper it is argued that Finnish modern architecture, which was experienced at first hand during these study trips, was perceived as an acceptable model for Baltic architects who wished to belong to the international community of modern architecture, while retaining a national idiom and a distinctive character within the USSR. Appropriating the regionalist features of modern Finnish design, the Baltic architects designed an urban environment which has been seen as exceptional, appropriating western cultural models much more quickly and with greater passion, and which has thus been labelled as 'the Soviet West'. It is important, therefore, to examine how Baltic architects pursued more individualised solutions; how ideological requirements were imposed during the Socialist period; and what precise Nordic and, in particular, Finnish architectural influences (tangible and intangible) played the most important role. The main source for this paper was archival research and the author's interviews with architects.
\end{abstract}

Keywords: Socialist modernism, Lithuanian school of modern architecture, modernism in Lithuania, Nordic influence, Vilnius, Lazdynai, Composers' Village, Čekanauskas 


\section{Introduction}

Architectural modernism in the post-war Baltic sea area, especially the socialist modernism of the former Soviet Baltic Republics, Estonia, Latvia and Lithuania, faces revision as regards the East-West interrelationship in culture during the Cold War (Caldenby and Wedebrunn 2010; Kalm and Ruudi 2005). The Baltic Republics have been described as exceptional, appropriating western cultural models much more quickly and with greater passion, and have thus been labelled as the 'Soviet West' or 'an inner Soviet abroad' (Gerchuk 2000, 82). I would argue that Baltic post-war modernist architecture (1956-1968) was strongly influenced by Finnish modernism, because the latter became an acceptable model for Baltic architects who wished to belong to the international community of modernist architecture, while retaining a national idiom and a distinctive character within the USSR. Finnish architecture played a special role in this process of modernization because it could be experienced at first hand during study trips in the late 1950s and 1960s (Kalm 2001; Hallas-Murula 2005; Drèmaitè 2013; Reklaitè 2014; Daubaraitè and Žukauskas 2018).

I would argue that Baltic post-war modernist architecture (19561968) was strongly influenced by Finnish modernism, because the latter became an acceptable model for Baltic architects who wished to belong to the international community of modernist architecture, while retaining a national idiom and a distinctive character within the USSR.
Political and economic reforms initiated by the Soviet leader Nikita Khrushchev, known as the 'Khrushchev Thaw' (1954-1964), enabled closer ties to be established between the West and the Soviet Union. This was clearly illustrated by the rapidity of Soviet adoption of Western technologies, standards and design canons, as several researchers have demonstrated (Péteri 2004, 113-123; Kohlrausch, Steffen and Wiederkehr 2010). Reform in construction and architecture was driven by the goal to combat a housing crisis and provide a separate apartment for every Soviet family by the 1980s. It called, therefore, for making the process of construction faster and cheaper and for validation of precast concrete construction. The Soviets were drawn to socially and technologically advanced French and Nordic housing policies, as witnessed by the growing number of official exploratory visits by architects, builders, and construction engineers from 1955 onwards (Report 1956; Erofeev 2019).

The favourable Soviet view of Finland (exemplified by the Agreement of Friendship, Cooperation and Mutual Assistance, known as the Finno-Soviet Treaty, 1948) resulted in numerous technological and expert exchange programmes. Publications about Finnish architecture began to appear in the Soviet press in 1956, and Khrushchev visited Finland in 1957. He was much impressed by what he saw in Tapiola, a modern residential suburb of Helsinki, and even directed Soviet planners to design several satellite new towns around Moscow (Kazakova 2018, 313-321). New residential districts were also the target of a Gosstroi (State Construction Committee) delegation to the Nordic countries in 1957 (Report 1957). The delegation of eight members, headed by Vladimir Kucherenko, the head of Gosstroi, spent thirty days (from 4 October to 5 November 1957) visiting new mass housing districts, planning offices and construction facilities in Sweden, Norway, Denmark and Finland. The newly developed satellite towns Vällingby (of Stockholm) and Tapiola (of Helsinki) were of special interest. Impressed by the landscape design in the housing districts, and by the economic profile and quality of finishing materials in the homes and public buildings they visited, the delegation recommended that the Soviet government acquire several production lines from Nordic manufacturers.

\section{Theoretical Approach: Symbolic Geographies of Soviet Baltic Modernists}

Susan E. Reid has observed that direct intervention by the regime in architecture made a fresh start mandatory, effectively giving the signal for a re-appropriation of international modernist design principles (Reid 2009, 99-100). For Baltic architects political reform in construction played an important, although different, role. The Thaw encouraged a process of cultural liberation that was characterized by a clear re-emergence of national, Western-oriented and modernist aspects of 
culture. Architects and designers were able to return to modernist aesthetics known from the pre-war period of independent national states and foreign architectural magazines. In the Baltic Republics modernism was a long-awaited turning point in architecture, since it was always connected with an alternative, even national, approach. John V. Maciuika noted that 'by grafting westward looking orientation onto local traditions, architects at the Baltic periphery of the Soviet Union kept alive an historical ambition to be included in a Western European national and cultural community' (Maciuika 1999, 24).

The concept of

'symbolic geographies': 'how human

agents, in particular historical and cultural contexts, define themselves by locating

themselves spatially as well as temporally, drawing the boundaries of social spaces where they are within, and relating themselves and their spaces to others' (Péteri 2010, 2-3).
Modernist architecture in the three Baltic Republics was closely connected with the emergence of a new generation of young local architects (born around 1930 and graduating in the mid-1950s), who felt a kinship with international modernism and favoured retaining their own national identities, seeking to avoid appearing too 'Soviet' in style, as can be understood from their interviews (Čekanauskas 2006; Brèdikis 2011). The young Lithuanian architects appointed to work in state planning and design institutions between 1955 and 1957 began to raise questions about issues that were particularly relevant to a national style of modern architecture: identity, construction materials, and the relationship between buildings and their surrounding landscape.

The concept of 'symbolic geographies', developed by György Péteri in his book Imagining the West in Eastern Europe and Soviet Union, can be helpful in understanding the goals and strategies of the young Lithuanian architects. The author showed 'how human agents, in particular historical and cultural contexts, define themselves by locating themselves spatially as well as temporally, drawing the boundaries of social spaces where they are within, and relating themselves and their spaces to others' (Péteri 2010, 2-3). What makes these socially and historically situated processes critically important is their intimate relationship to the formation of identities.

As the socialist realist programme was ditched and Lithuanian designers sought to create something alternative to Soviet architecture, the 'Golden Era' of national architecture, namely the modernism of the independent Republic of Lithuania (1918-1940), became an important source of inspiration and can be seen as a temporal symbolic geography. The building that first delineated the transition from Stalinism to modernism and illustrated well the aspirations of the new generation of architects was dedicated to architecture. The State Urban Construction Design Institute in Vilnius (architect Eduardas Chlomauskas and engineer Česlovas Gerliakas, 1959-1961) was the first building to be specifically constructed for a large state design office (employing over a thousand people) and it featured numerous clear influences from 1930's Kaunas architecture. The heritage of Kaunas modernism of the 1930s played a significant role in shaping post-war Lithuanian modernist vocabulary, not only through the continued use of similar materials and construction technologies but also symbolically. Nevertheless, according to architect Justinas Šeibokas (1929-2015), by 1960 Lithuanian architects of his generation 'had seen enough of pre-war Lithuanian architecture' and sought new, modern sources of inspiration for their work and self-identity (Šeibokas 2010).

Another wellspring of inspiration, which could be described as a spatial symbolic geography, was the contemporary Western architecture increasingly accessible through foreign journals and magazines. However, knowledge of international developments in the late 1950s was scarce. As opportunities for tourist travel increased in the late 1950s, the USSR Architects' Association (UAA) began to organize professional delegations who were dispatched on fact-finding missions to 'capitalist countries'. Previously, members of the Lithuanian SSR Architects' Association (LAA; each national republic had its branch subordinate to the UAA) had travelled on several official visits to socialist countries such as Poland and Czechoslovakia, but missions were more often organized to different cities within 


'We really felt
architecture
there,'
the famous
Lithuanian
post-war
modernist
Vytautas
Edmundas
Čekanauskas
(1930-2010)
recalled.
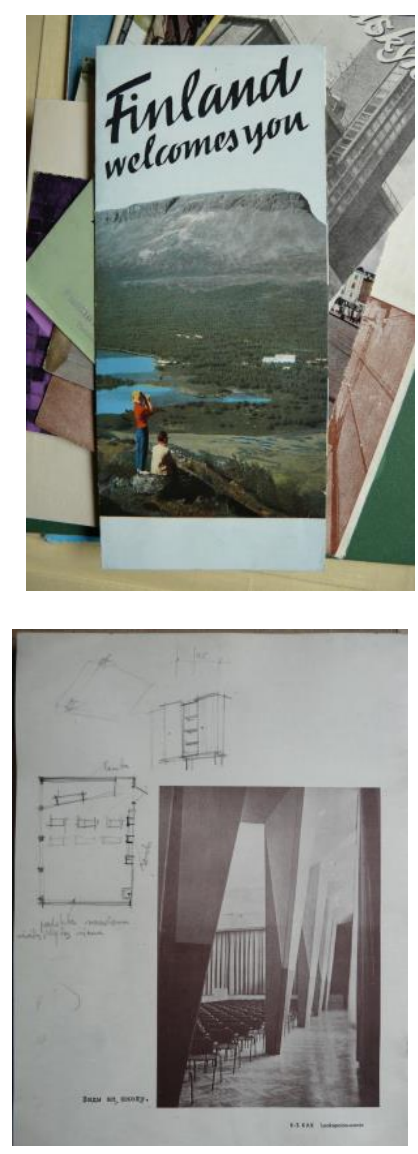

Figure 1. Flyers and brochures from trips to Finland in the 1960s, private collection of V. E. Čekanauskas the Soviet Union (Moscow, Leningrad, Kiev, Kaliningrad, or Sverdlovsk). Three or four such trips were organized each year, with delegations usually consisting of twenty or so architects.

During the official fact-finding trip to Finland, which was organized in June 1959 by the UAA, a group of twenty-one specialists from the Baltic Republics and Leningrad (today St Petersburg), including six Lithuanian architects, were allowed to visit the most desirable West (Materials 1959). 'We really felt architecture there,' the famous Lithuanian post-war modernist Vytautas Edmundas Čekanauskas (1930-2010) recalled (Drèmaitè, 2006, 32-39). A second Soviet delegation of twenty-six specialists visited Finland in August 1959, which included six architects from Lithuania representing major design institutes, mainly chief architects and engineers (Materials 1959). In 1960 UAA organized three missions to Finland, including a total of ninety Soviet architects (Materials 1960), and one delegation was made up exclusively of nearly thirty Lithuanian architects (Mačiulis 2011, 39). From 1959 onwards foreign travel was made easier for local republican trade union administrations to organize, facilitating further visits by Lithuanian architects to Finland in 1961, 1963, 1964 and in later years. The proximity of the Baltic Republics to the Nordic countries made it a benchmark for Lithuanian architects, with Finland the most frequently visited country for fact-finding trips.

\section{Destination Finland: Lithuanian Architects Meet Architecture}

What did they visit, and what was their impression? Routes of architectural tours re-created from official documents and personal archives (Program 1959; Daubaraitè and Žukauskas 2018) reveal that, over a period of ten days, delegation members ordinarily visited several brick and wood processing factories, new residential complexes and apartment houses, the University of Turku (designed by Aarne Ervi, 1956-1959), Jyväskylä University (Alvar Aalto, 1950) and Säynätsalo City Hall (also Aalto, 1950-1952) and the highlights of modern Helsinki: the Olympic stadium (Lindegren, Jäntti, 1934-1952), the House of Culture (Aalto, 1955-1958), the National Pensions Institute (Aalto, 19521956), and the suburb of Tapiola. In June 1959, architects were given the opportunity to meet with Tapiola's designer, Aarne Ervi, and later visited the offices of Alvar Aalto (though the prominent architect was away at the time). A similar opportunity was offered in 1964 for a delegation of Lithuanian builders and construction engineers, only with Jyväskylä replaced by Tampere and a visit to the Lenin museum there (Program 1964). These well-prepared tours proved the high efficiency of Finnish travel agencies in showing modern architecture to the groups of Soviet architects.

Archives also show that architects were allowed to make requests for foreign travel (though not always fulfilled), and Nordic countries featured more than others in these requests (Files 1961). One needed to belong to the Architects' Association to be allowed to join the carefully controlled and supervised trip, which on its own had to be approved by the central boards in Moscow. Candidates were carefully selected and it was obligatory for the groups to be 'convoyed' by Intourist guides (mainly KGB employees). In later years, Finnish travel agencies began specializing in organizing tours of modern Finnish architecture and construction trade fairs for Soviet technocrats.

The positive approach to Nordic architecture was well reflected in the official media of the period. The main Lithuanian professional magazine Statyba ir architektūra (Construction and Architecture) in 1961 started publishing articles about Finnish and Swedish architecture alongside reports from the Socialist countries. With the introduction of Nordic architecture, the hostile approach towards western modernism started to change, because advances in technology were recognized. A characteristic example is a paper by Jonas Minkevičius, an 
official commentator of contemporary architecture in Soviet Lithuania, where obligatory ideological critique of Western capitalism was still present, yet technological advances in housing construction were positively presented: 'Finnish architecture is exceptional among the other Nordic countries because it is moderate and nationally distinctive. Disregard the fact that most of the buildings are individually designed (sic!), they feature creative method and careful respect for nature. Finnish architects do not achieve this through fashionable formalism, nor through the application of traditional architectural ornamentation. Contemporary Finnish architecture is deeply embedded in the folk tradition and features rational simplicity, organic connection to nature, and moderate composition' (Minkevičius 1961, 9-12). The author referred to the 'people's tradition' in an attempt to match regionalism to an official Marxist ideology, but Lithuanian architects did not appear to be attracted by obligatory rhetoric. They saw much more than effective housing construction, and shared sincere emotional attraction when describing their own experiences of the Nordic architecture.

Architects Algimantas Mačiulis (Mačiulis 1961, 20-23), Nijolè Bučiūtè (Bučiūtè 1964, 21-23) and Eugenijus Gūzas (Gūzas 1965, 34-37) emphasized the connection of architecture with the natural environment, the use of natural local materials, and the excellent use of natural terrain and trees in Tapiola. Builders and engineers published very favourable impressions of the high quality of construction in Finland and Sweden (Statybos metodai... 1961, 23-26; Sargelis 1964, 27-28; Matijošius 1965, 10-11). All their texts almost glorified Nordic design and construction, its novelties, quality, functionality, economy, logic, materials, and relation to the natural environment.

Figure 2.Vytautas Edmundas Čekanauskas presents an album of Vilnius drawings by Mecislovas Bulaka to Aarne Ervi (first from left), Tapiola, Finland, 1959 , private collection of $\mathrm{V}$. E. Čekanauskas

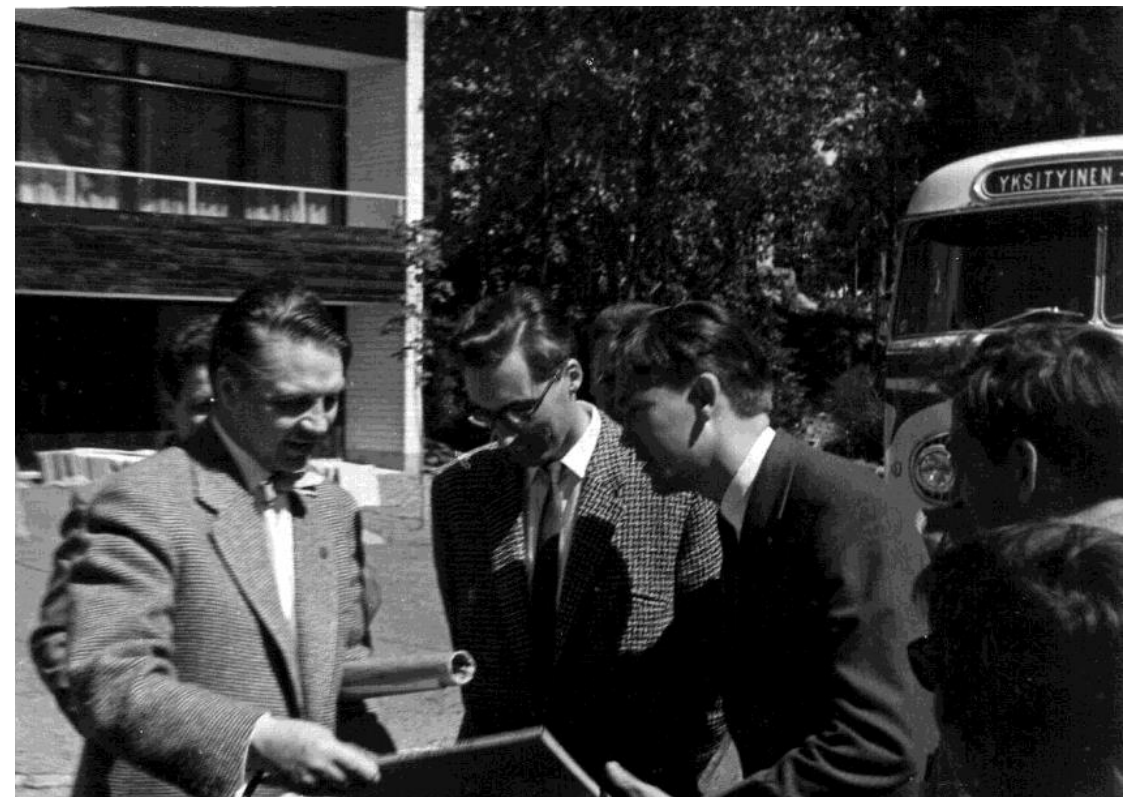

The visiting Lithuanian architects brought home markedly emotional impressions. Many of them referred to Finland as a symbol of modern architecture that influenced their later work. Algimantas and Vytautas Nasvytis asserted that they embraced 'a Finnish-Nordic way of thinking, perceived through the works of Ervi, Aalto and others' (Mačiulis 2007, 102). Šeibokas said that 'direct contact with new Finnish architecture was a critical creative breakthrough - we began to design completely differently' (Šeibokas 2010). Vytautas Brèdikis recalled: 'I had my own metaphysical version, but reality proved to be otherwise. Buildings with unique architecture, well-arranged surroundings. Simple people interacting naturally. Good, humane architecture. A masterful harmony of buildings and nature' (Brèdikis 2011). Čekanauskas remembered the trip as having a lasting impression on him. Visiting Aalto's office, getting a close look at Finnish

KEYNOTE SPEECH 
architecture, seeing the suburb of Tapiola, and meeting its principle architect Ervi, were, for Čekanauskas, indescribable events. Probably the most precious of all relicts, a sketch with an Alvar Aalto autograph, about which all later generations of Lithuanian architects have heard, is still kept in the very centre of Čekanauskas' work room. Čekanauskas made an attempt to explain his emotions rationally, searching for historical similarities between Finland and Lithuania and referring to their shared history of Imperial Russian oppression in the $19^{\text {th }}$ century, independent nation state construction since 1917 and 1918, agricultural background and feeling for the natural environment (Maciuika 2019). Everybody mentioned the unforgettable architecture of Aalto, the harmony between the buildings and the natural environment, the human scale, the varied typology and excellent design of residential buildings, interesting community centres, and the good combination of modern and natural materials in construction and décor.

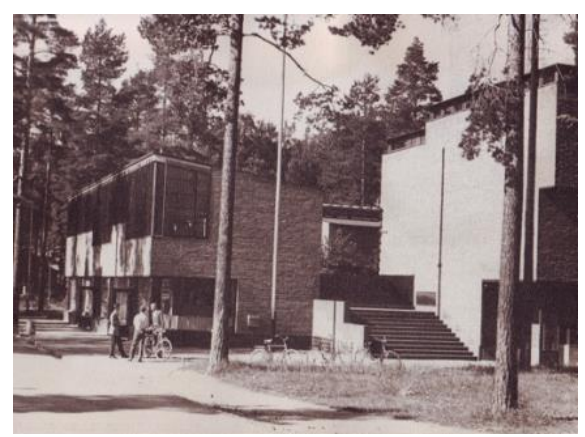

Figures $3 a, 3 b$ and $3 c$. Slides by Algimantas Mačiulis from his trip to Finland, 1960s, private collection of $A$. Mačiulis
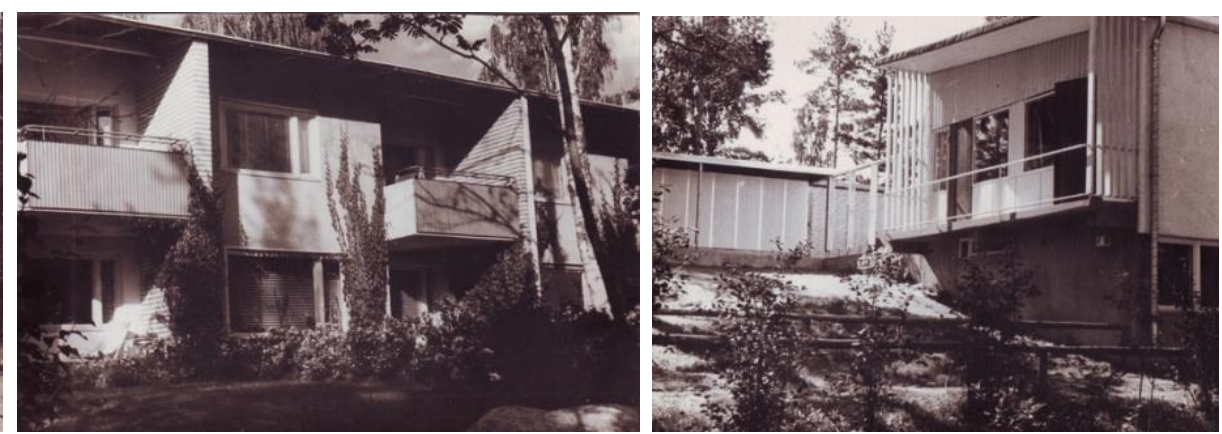

\section{Reflections of Finnish Modernism in Lithuanian Post-War Architecture}

It seems that the 1930s generation of young Baltic architects who began their careers in the 1960s were especially attracted to Finnish pre-war and post-war modernism. Similar influences were felt in Estonia, where the connection with Finland was even closer, facilitated by language, geographical proximity, a new ferry line between Tallinn and Helsinki, and Finnish television. In his book on Estonian Architecture of the $20^{\text {th }}$ century, architectural historian Mart Kalm even titled a chapter 'Modelled on post-war Nordic architecture' (Kalm 2001, 325-326). It can be assumed that post-war Finnish architecture offered a modern interpretation of traditional values, and promised to boost national identity as well as the Baltic architects' own desire for distinctiveness within the Soviet Union. In the 1960s Lithuanian architects attributed the following characteristics to modern Finnish design: subtle and simple shapes, harmony between the buildings and the natural environment, human scale, and good combination of modern and natural materials. It is interesting to note (and compare) that, when in 1983 Lithuanian architects decided to define the features of contemporary Lithuanian architecture, they mentioned moderate and simple shapes, human scale, connection with nature, and respect for the environment (Vanagas 1983, 5).

\section{The Decade of the Interior}

Changes brought about by modernism appeared first in interior design, the field of architecture that lent itself easily to rapid progress. Here ideas could be implemented much faster, a factor that appealed to a generation of young architects, designers and artists longing to espouse modern national design aspirations. Khrushchev's Thaw led to the removal of the heavy interior curtains and dark massive furniture pieces favoured by Stalinist-era restaurants, replacing them with large, bright spaces, light furniture, modern lighting fixtures, openwork dividers and geometric decor features. The result was the emergence of the local 'Lithuanian Interior Design School', launched by the twin brother architects Algimantas (1928-2018) and Vytautas (1928-2016) Nasvytis. They designed the interior of the modern Neringa Café in Vilnius in 1959, which signaled a turning point in architecture. The interior consisted of four interlinked spaces: the lobby, 
a bar, and large and small halls, all finished in new, modernist forms and different natural materials (wood, metal, ornamental plastering and glass). The creative process combined the Nasvytis brothers' knowledge of folk art (with inspiration from pre-war Kaunas café culture) and an understanding of the spirit of Alvar Aalto (still the pre-war Aalto, Villa Mairea for example, perceived only from architectural journals). The architects succeeded in combining modern aesthetics with a national Lithuanian narrative, embodying a concept that showcased a new elite style.

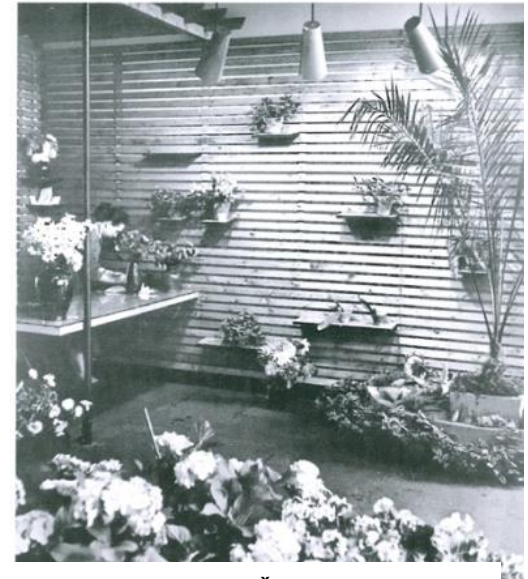

Figure 4. Justinas Šeibokas, Interior of the Flower Pavilion in Vilnius, 1961, private collection of J. Šeibokas
Neringa Café was followed by the renovation of many other cafes and restaurants and the construction of new ones. All of these minimalist interiors shared certain traits that, together, can be considered characteristic of early Lithuanian post-war modernism: natural materials (wood shelves coated in transparent varnish, redbricked walls and coarse plaster) and a wealth of artwork (metalwork, stained glass, wall paintings, mosaics, ceramics, and openwork partitions made from various different materials). Artwork was used to impart a national theme to the interior, incorporating folklore motifs from Lithuanian fairy tales, legends and songs. Interestingly, floral shops (and their interiors in particular) also became harbingers of modernism. The interior of a floral store designed by Justinas Šeibokas in 1961, for example, signaled a breakthrough in architecture for his peers. His design was notable for a new concept of space and colour, and the role played by light, elements that the author, according to his memoirs, adapted from Finnish architecture (Šeibokas 2010). A widely acknowledged Soviet material and technological scarcity motivated the creative talents of local architects, while the aesthetics of simplicity were dictated not only by the modern approach of designers but also by limited funds and a constant shortage of materials. For example, architects and designers found an innovative way to adapt the spherical body of the Lithuanian-made 'Saturnas' vacuum cleaner, then produced at the Vilnius Electric Welding Appliances Factory, using the body of the machine to create light fixtures (for the Dainava Restaurant) or globe lights (for the Composers' Concert Hall and the café at the Art Exhibition Hall).

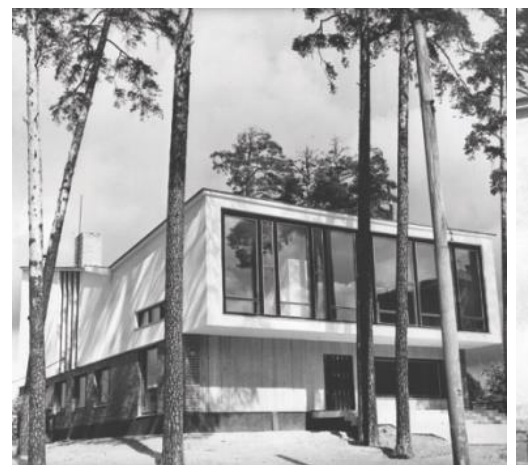

Figures $5 a, 5 b$ and $5 c$. The Composer's Village in Vilnius, designed by Vytautas Edmundas Čekanauskas and Vytautas Brédikis, 1960-1966, post-construction photos from private collection of V. E. Čekanauskas
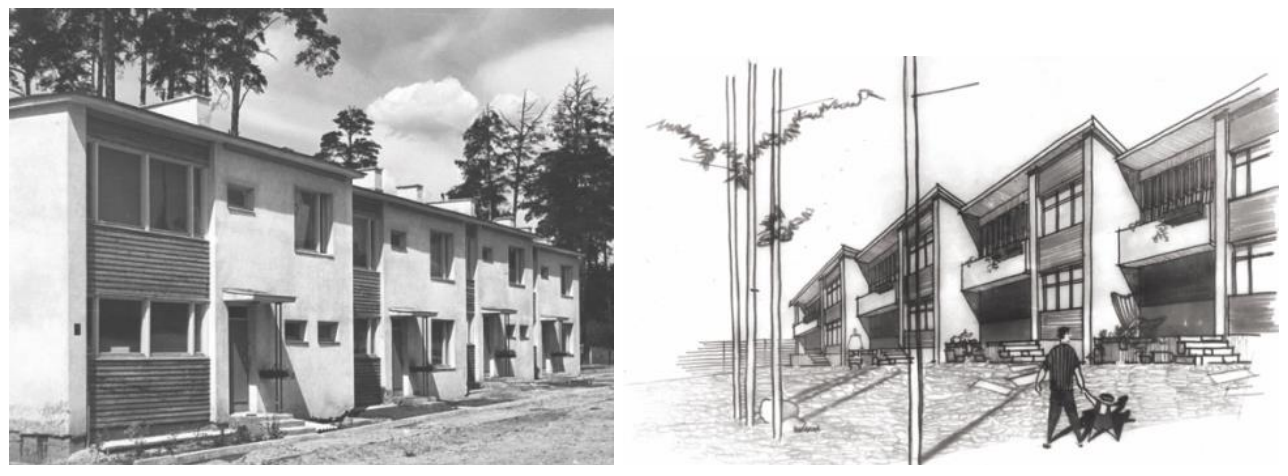

The Cosy Village of Composers

One of the most vivid examples of direct Finnish influence was the Composers' Village in Vilnius, built in 1960-1966. It was indeed a unique construction in the history of Soviet housing - through their connections with the Communist Party's Central Committee and the Vilnius Executive Committee (equivalent to municipality), the Composers' Association of the Lithuanian SSR managed to obtain both an empty plot of land by the Neris River in 1958 and approval for a custom design. Once approval was obtained, the Urban Construction Design Institute announced an in-house competition in 1959, which was won by two young architects, Vytautas Čekanauskas and Vytautas Brèdikis, who developed a low-rise group of buildings (sixteen single-unit houses and a concert hall), thus preserving the surrounding historic area from the intrusion of standard five-floor pre-fab houses (Design 1960).

Čekanauskas recalled that his trip to Finland in 1959 helped him to decide both on the use of predominantly traditional, natural and locally available building 
materials (red brick, rough plaster and timber) and the incorporation of buildings into the natural landscape, preserving the surrounding pine trees (Čekanauskas 2006). The architecture of the complex had much in common with the Helsinki suburb of Tapiola, for example, with houses on Kontiontie Street designed by Kaija and Heikki Siren in 1955. As in Finland, the composers' flats in the Vilnius suburb of Žverrynas were simply furnished, yet functional. There were two types of apartments: a three-room unit (in total $55 \mathrm{~m}^{2}$ in living space) and a four-room unit $\left(66 \mathrm{~m}^{2}\right)$. Each unit had a kitchen with an adjacent pantry, a living room, one or two bedrooms, a composer's workroom, two bathrooms (one with a bath), and a spacious balcony and terrace. Balconies looked out onto the forested banks of the Neris River. The dividing wall between kitchen and living room was a specially designed partition and shelving unit with a window opening in the middle to allow food to be passed from the kitchen to the living room.

The creative partnership between Čekanauskas and Julius Juzeliūnas, the chairman of the Composers' Association, continued with the former designing a minimalist home office interior for Juzeliūnas, with wooden bookshelves running the entire length of one wall. Local Lithuanian media featured the architecture of the Composers' Village; and the entire complex, including the interior of Juzeliūnas' apartment, was showcased in the prestigious Czech design magazine Domov (1968, No. 2). The individual approach used in the design of the Composers' Village, including the incorporation of outside decks beside each house, clearly spoke to the superior quality of the new housing development.
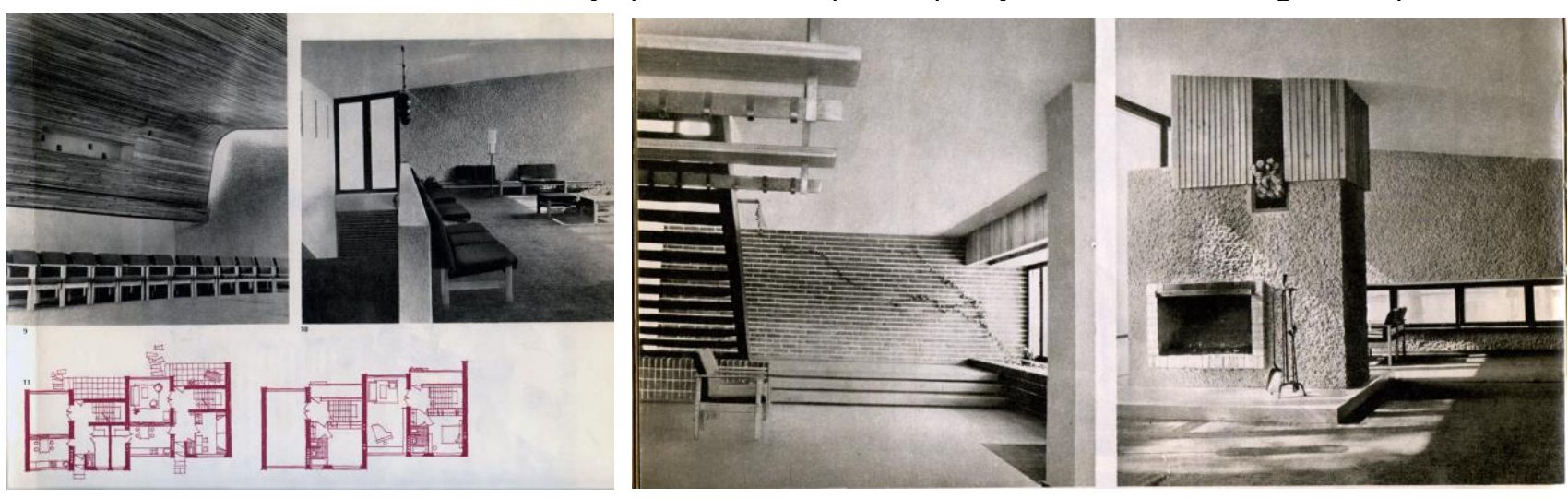

Figures $6 \mathrm{a}$ and $\mathbf{6 b}$. Interior of the Composer's Hall of Music was featured in the Czech design magazine Domov, 1968, No. 2, pp. 47-48
The Composers' Concert Hall, completed in 1966 adjacent to the housing, also followed an original design solution, showcasing a special sensitivity for, and thorough presentation of, Čekanauskas' fondness for Finnish architecture, particularly the work of Alvar Aalto. The building's exterior silhouette was shaped by a stylish element of 1940s international modernism: an inward sloping concrete roof (also known as a 'butterfly roof'), with walls finished in an entire array of natural materials, including wood, red brick, and a combination of decorative plaster and glass. The landscaping was laced with terraces created by low-rising stone walls. The interior has a wealth of motifs characteristic of Finnish modernism: narrow, vertical shelving, a wall of unfinished red brick extending into the interior space from the outside, a wide staircase without railings, a monumental stone fireplace, and large windows on both the ground and first floors which joined the interior and exterior spaces. The main hall ceiling, finished with undulating thin strips of wooden panelling is nearly identical to Aalto's Viipuri Library lecture hall (1935), where considerable attention was also focused on the room's acoustic conditions. There were also other details that testified to the architect's focus on the building's interior design: 'I loved the Composers' building very much. I even brought in my wife's cactuses, to suit the style. I also purchased a large plant, brought it over, and hung it [at the Union building]' (Čekanauskas 2006). 
The Composers' Village can be seen as incorporating both emotional and social aspects of modern Nordic architecture, evidenced by the functional planning of interiors and the creation of unique residential spaces. These factors were clearly shaped by a direct exposure to Finnish architecture, but one should also note the importance of informal relationships which helped to ensure the realization of original concepts. The incorporation of such a structure into its natural surroundings and the modernism of local materials came to be considered as an expression of a unique Lithuanian national architecture. The complex became famous throughout the Soviet Union for its unique typology and integrated architectural expression.

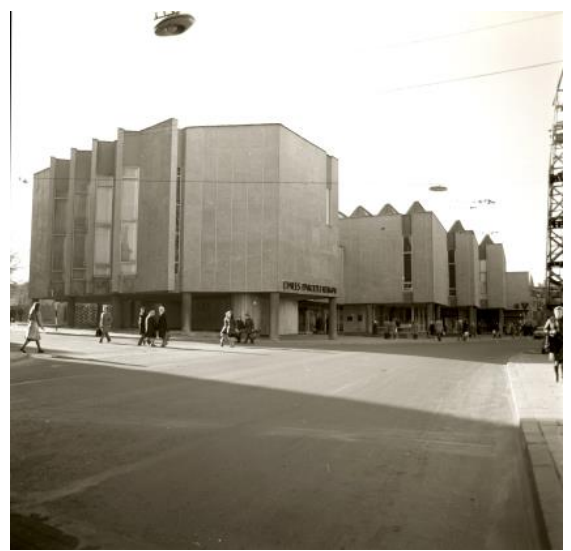

Figure 8. The Art Exhibition Hall in the historic centre of Vilnius, designed by Vytautas Edmundas Čekanauskas, constructed in 1965-1967, photo by Romualdas Rakauskas, private collection of V. E. Čekanauskas

\section{Modern Architecture in the Historical Environment: The New Art Exhibition Hall}

During their trips abroad, especially to Finland, architects were impressed by the harmony achieved between modernist buildings and their environment, both natural and urban. Since historical urban quarters continued to be important for Lithuanian architects as an inspiring national heritage, new buildings in the historical urban environment required sensitivity. The Art Exhibition Hall (19651967) by Čekanauskas became one of the prominent examples of 1960s modernism, designed to blend harmoniously with the architecture of the surrounding Vilnius Old Town. In line with the popular trend of the 1960s to enrich historical urban spaces with modern architectural structures, it was decided to build the Art Exhibition Hall on a site in the middle of the historic centre of Vilnius, cleared of the rubble of World War II. The site stood empty for a considerable time until the approaching anniversary of the October Revolution brought new funds and a directive to urgently construct a new facility for the exhibition of contemporary art. Fascinated by the works of Alvar Aalto, the architect used his Wolfsburg Cultural Centre in Germany (1958-1962) as an inspiration. It seems that Aalto's project with its low rise two-storey building and the cubic volumes of the auditorium, which was carefully integrated into natural mountain scenery, made an impression on Čekanauskas in his search to carefully position a new building in the sensitive old town urban environment. Indeed, the Art Exhibition Hall was recognized as a successful example of new architecture in its historical surroundings - Čekanauskas unveiled views of the bell tower of the All Saints Baroque Church which was visible through the new glass junction. He also masked the standardized prefabricated concrete panels used to construct the building with various decorative solutions (pale rough plaster and local dolomite tiles). 'The Western style' building, as it was perceived by locals, and its café became very popular among artists in 1960s and 1970s Vilnius.

\section{Lazdynai, the Lithuanian Tapiola}

Lazdynai, a huge mass housing residential area in Vilnius for forty thousand inhabitants, became a real highlight of the new Baltic housing design. After several unsuccessful mass housing design competitions, new and young architects Brèdikis and Čekanauskas at the Urban Planning Institute were commissioned to design Lazdynai in 1962 with an expectation of fresh ideas. Within the context of socialist standardization, the improvement of residential architecture became a central task for many architects. Both Čekanauskas and Bredikis talked about the strong influence of Finnish (Tapiola), Swedish (Vällingby, Farsta) and modern French (Toulouse-Le Mirail) suburban design (Čekanauskas 2006). The influence of Finnish and Swedish satellite towns is evident here in terms of the neighbourhood unit concept (as a Soviet microdistrict analogue) with semi-open courtyards and pedestrian avenues, development of alternative housing types, as well as adaptation to naturally hilly terrain. The pine trees in the entire area were preserved and integrated as part of the landscape design.

Lazdynai was the first part of Vilnius city development, designed as a series of suburbs threaded together on the main transport highway (Avenue of the 
Cosmonauts). Following the model of Stockholm's suburban expansion, this artery was isolated from the residential area by a ring road (which was later named Street of the Architects (sic!)) that connected four residential microdistricts. Internal roadways and pedestrian paths ensured safe connection within the residential area and with the central cultural and commercial buildings where all these avenues intersected. There was to have been an ambitious centre of Lazdynai erected on a platform above the highway (as in Vällingby), however it was never executed. According to its architect Česlovas Mazūras, the building was not only difficult to construct technologically, but also financially. It was, therefore, constantly delayed and finally rejected (Mazūras 2011).

Figure 8. Lazdynai, a large mass housing estate in Vilnius, designed by by Vytautas Edmundas Čekanauskas and Vytautas Bredikis, constructed in 1969-1973, photo by Romualdas Rakauskas, private collection of V. E. Čekanauskas

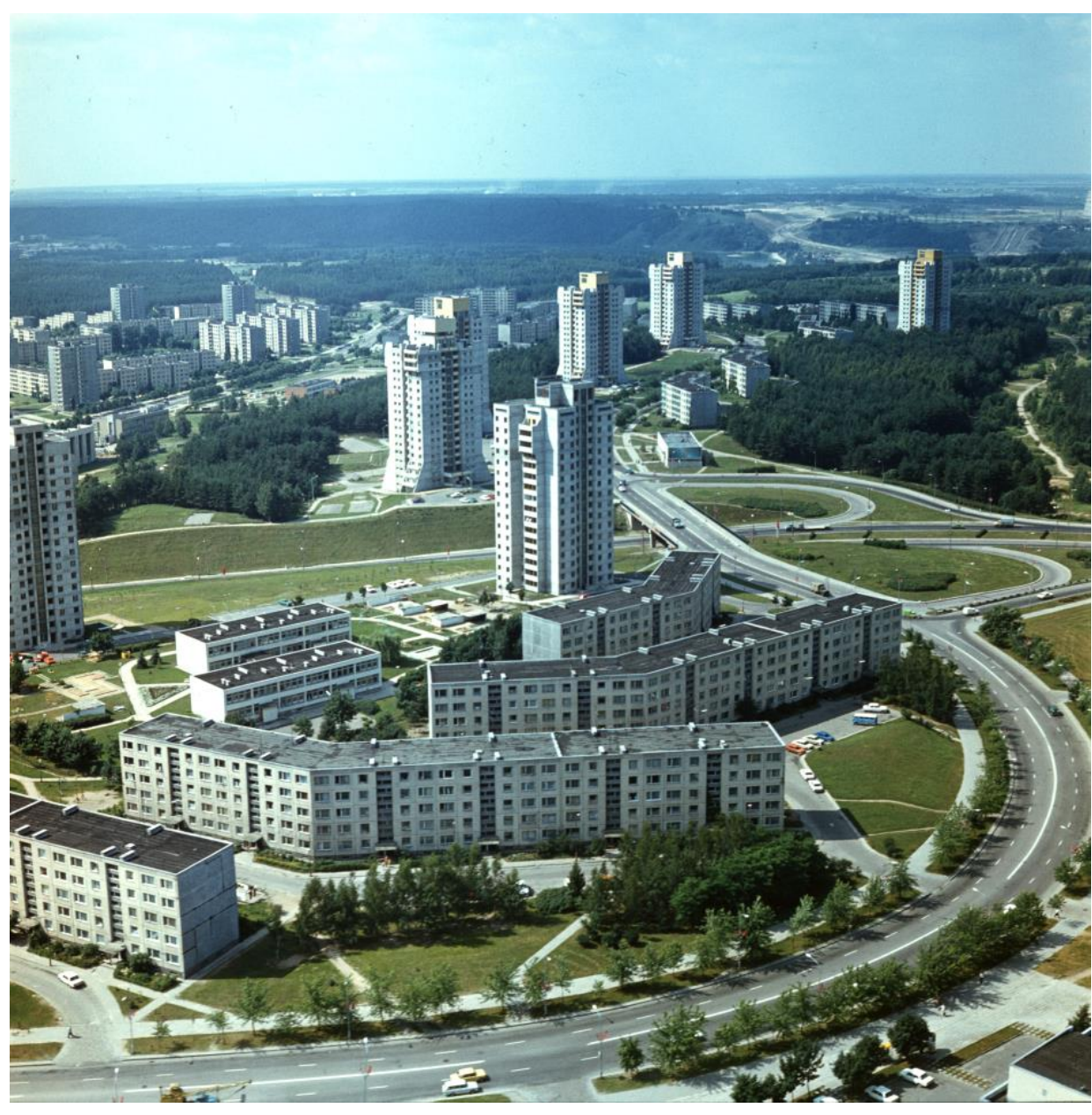

Another important aspect of Lazdynai was the introduction of different volumes of prefabricated houses which, following Nordic practice, was intended to create urban diversity and a distinctive silhouette. The site for Lazdynai was naturally hilly and well forested - features that would be preserved as elements in the final landscape design (as in Tapiola). Lazdynai's architects advocated setting standard five and nine-storey housing blocks among the existing hills (the real challenge was to place houses across the slope) to create a unique silhouette for the community. This proposal, however, required different housing block designs. So architects collaborated closely with the Standard Design Department of the Vilnius Urban Construction Planning Institute and developed fifteen improved versions of the existing standard building series I-464 (Design 1970). The twelvestorey pre-cast panel towers were initially chosen because of their aesthetic contribution to the overall composition. Eventually, however, pre-cast panel construction for towers was declared inefficient by Soviet economic planners. The diverse range of building types in Lazdynai was meant solely to address an architectural issue, unlike in Finland or Sweden, where different types of housing 
architectural issue, unlike in Finland or Sweden, where different types of housing solutions were also aimed at satisfying the needs of different types of families.

Though the production of these new types of buildings posed a challenge to the Vilnius Panel Construction Factory and required additional funding, the architects maintain that a certain amount of interpersonal connections between architects and local communist party and municipal leaders played an important role in supporting the innovations. For example, the planners were committed to build all public buildings (schools, kindergartens, shops and micro-district centres for shopping and communal services) following standardized designs; however, they individually detailed them with original characteristics which featured especially in public art. The same could be said of school design. After two standard schools were built, the young architect Mazūras decided to escape the standard design and introduced original terraced planning (on the slope) and materials (red brick in combination with concrete panels). He also believed that cluster composition (in contrast to the standard corridor system) would 'liberate the souls of the future generation' (Mazūras 2011). Two schools were built in Lazdynai in accordance with his unique design, strongly linked to Nordic design in terms of undecorated red brick inner and outer walls, use of wood and bright colours, as well as the inclusion of many open spaces inside the building.

After several visits of leading figures of the State Construction Committee, Lazdynai was nominated and later awarded the Lenin prize for the All-Union Architectural Design in 1974 (it was the first time that a large mass housing estate was awarded the highest prize). Following this award, Lazdynai became widely featured at home and abroad with such optimistic headlines as 'Sunny City Blocks', 'A Harmony of Nature and Stone', 'Beauty for Everyone', 'Architects' Street', 'Creativity in Mass Housing', culminating in a front cover-feature for the Eastern Bloc's international survey of modern panel housing construction (Rietdorf 1976). Articles in the Lithuanian and Soviet press pointed to the diversity of buildings constructed in Lazdynai as a sign of its superior quality, emphasizing that as many as fifteen different types of houses had been used, a record for industrial construction. Meanwhile, Rietdorf's book about new residential construction in Socialist countries praised the Lazdynai architects and their ability to create compositional diversity using only (!) fifteen different types of building designs (Rietdorf 1976).

Why was Lazdynai so successful? Clearly, the district's design was overseen by two very talented architects, Brèdikis and Čekanauskas, with many other architects contributing to details and various designs of individual public buildings. In total, nearly one hundred and fifty specialists from the Urban Construction Planning Institute contributed to the Lazdynai project. Planners had come to value the purposeful shaping of the residential environment, understanding that residents needed more than just an apartment - they also benefited from a well-organized service system and natural parks. However, the ideological part of the story was no less important. It is very likely that local Communist Party leaders viewed the project as a model design. At the time the Soviet mass panel housing system was subject to a wave of criticism for being monotonous, depressing and low quality. In this context Lazdynai demonstrated the possible (bright) future of standardized panel construction, which only needed a touch of 'landscape design' and 'better architecture' with inspiration from Nordic study tours.

\section{Conclusion}

Finnish post-war modernism became an acceptable model for Soviet Baltic architects since it combined modernist design with the regional approach and thus matched their aspiration for national idiom. It might explain why Finnish inspired aspects of modernist architecture in Lithuania can be seen not only in 
the area of exceptionally designed public buildings that marked the breakthrough of modernism, but also in the field of prefabricated mass housing estates.

The architects admit that study trips changed their designs in terms of materials, planning and location in the natural environment. This was well reflected both in interior design and the new approach to urban heritage. It is interesting to note that, until the Khrushchev Thaw, Lithuanian architects rarely saw Nordic countries as an architectural model, while French, Italian and German architecture attracted greater attention. But, in the post-war period, its close geographical location and reputation for contemporary architecture made Finland one of the most favoured destinations for Lithuanian architects. Because of its good cultural connections with the USSR it became the most visited foreign country.

Lithuanian architects perceived the Nordic architecture of the 1950s as a successful combination of contemporary design and regional distinction. Experiencing Finnish contemporary architecture at first hand, they understood that the national (or regional) idiom might be retained not through the direct application of folk elements, but in the contemporary combination of local natural materials with innovative construction and respect for the natural environment.

\section{References}

Bučiūtè, N., 1964. Naujosios suomiu architektūros bruožai [Points of the New Finnish Architecture], Statyba ir architektūra 1, pp. 21-23.

Caldenby, C. and Wedebrunn, O. eds., 2010. Living and Dying in the Urban Modernity. Nordic-Baltic Experiences, The Royal Danish Academy of Fine Arts.

Crowley, D., 2009. Socmodernism and the architecture of leisure in Eastern/Central Europe in the 1960s and 1970s, in: Different Modernisms, Different Avant-gardes: Problems in Central and Eastern European Art after World War II, Tallinn.

Daubaraitè, J. and Žukauskas, J., 2018. Matkat Suomeen 1959 ja 2017 / 1959 and 2017 journeys to Finland, Arkkitehti 4, pp. 81-87.

Drëmaitè, M., 2006. Vytautas Edmundas Čekanauskas as a Romantic Modernist, Archiforma - Lithuanian Architectural Review, No. 4, pp. 32-39.

Dremaitè, M., 2013. Modern Housing in Lithuania in the 1960s: Nordic Influences, in: Caldenby, C. and Wedebrunn, O., eds., 2013. Survival of Modern: from Cultural Centres to Planned Suburbs, Copenhagen: The Royal Danish Academy of Fine Arts, School of Architecture, pp. 80-91.

Erofeev, N., 2019. The I-464 Housing Delivery System: A Tool for Urban Modernisation in the Socialist World and Beyond, Fabrications, 29.2, doi: 10.1080/10331867.2019.1611255.

Gerchuk, I., 2000. The Aesthetics of Everyday Life in the Khrushchev Thaw in the USSR (1954-64), in: Reid, S. E. and Crowley, D. eds., 2000. Style and Socialism. Modernity and Material Culture in Post-War Eastern Europe, London: Berg, p. 82.

Gūzas, E., 1965. Saulèta suomiụ architektūra (iš kelionès ispūdžių) [Sunny Finnish architecture (travel memories)], Kultūros barai, 6, pp. 34-37. 
Hallas-Murula, K., 2005. Soome-Eesti: sajand arhitektuuri suhteid [FinlandEstonia: a century of architectural relations], Tallinn: Eesti Arhitektuurimuuseum.

Kalm M., 2001. Eesti 20. Sajandi arhitektuur/ Estonian 20 ${ }^{\text {th }}$ Century Architecture, Tallinn.

Kalm, M. and Ruudi, I. eds., 2005. Constructed Happiness: Domestic Environment in the Cold War Era, Tallinn: Estonian Academy of Arts Proceedings 16.

Kazakova, О., 2016. Зеленоград, 1958-1975, in: Броновицкая А., Малинин, Н., 2016. Москва: архитектура советского модернизма 1955-1991. Справочник путеводитель. Москва: Garage, с. 313-321.

Kohlrausch, M., Steffen, K. and Wiederkehr, S., eds., 2010. Expert Cultures in Central Eastern Europe: The Internationalization of Knowledge and the Transformation of Nation States since World War I, Osnabrück: fibre.

Maciuika, J. V., 1999. East Block, West View: Architecture and Lithuanian National Identity, in Traditional Dwellings and Settlements Review, University of California Press, 1999, Vol. XI, No. 1, pp. 23-35.

Maciuika, J. V., 2019. Lithuanian Architects Speak Out About The Soviet Era: The 1992 Oral History Tapes, Vilnius: Lapas (forthcoming).

Mačiulis, A., 1961. Apie suomių architektūrą [On Finnish Architecture], Statyba ir architektūra. 1961, 1, pp. 20-23.

Mačiulis, A., 2007. Architektai Algimantas ir Vytautas Nasvyčiai, Vilnius: Vilniaus dailès akademijos leidykla.

Mačiulis, A., 2011. Vytautas Edmundas Čekanauskas, Vilnius: Vilniaus dailès akademijos leidykla.

Matijošius, K., 1965. Pas Suomijos mūrininkus [Visiting Finnish bricklayers], Statyba ir architektūra 6, pp. 10-11.

Minkevičius, J., 1961. Nacionalinès išraiškos ieškojimai užsienio architektūroje [Searching for National Expression in Foreign Architecture], Statyba ir architektūra, 3, pp. 9-12.

Péteri, G., 2004. Nylon Curtain - Transnational and Transsystemic Tendencies in the Cultural Life of State-Socialist Russia and East-Central Europe, Slavonica, 10, No. 2, pp. 113-123.

Péteri, G., ed., 2010. Imagining the West in Eastern Europe and the Soviet Union, Pittsburgh University Press, 2010.

Reid, S. E., 2009. The Soviet "contemporary style": a socialist modernism, in: Different Modernisms, Different Avant-gardes: Problems in Central and Eastern European Art after World War II, Tallinn: Proceedings of the Art Museum of Estonia, pp. 99-100.

Reklaitè, J., 2014. Amber inclusions. What modernist memorabilia can tell us, in: Drèmaitè, M. and Reklaitè, J., eds., 2014. Modernism: Between Nostalgia and Criticism, Vilnius: Vilnius University and Architecture Fund, [online] Available at: $<$ http://leidiniu.archfondas.It/en/alf-02/julija-reklaite-amber-inclusions-whatmodernist-memorabilia-can-tell-us> [Accessed 22 July 2019]. 
Rietdorf, W., 1976. Neue Wohngebiete sozialistischer Länder, Berlin: VEB Verlag für Bauwesen.

Sargelis, V., 1964. Gyvenamoji statyba Švedijoje [Housing construction in Sweden], Statyba ir architektūra 11, pp. 27-28.

Statybos metodai Švedijoje [Construction methods in Sweden], 1961. Statyba ir architektūra 1, pp. 23-26.

Vanagas, J., 1983. Amžinai gyvas grūdas [The Seed is Alive Forever], Literatūra ir menas, 28 April, p. 5.

Algirdas Jonas Ambrazas, Julius Juzeliūnas: gyvenimo ir veiklos panorama, kūrybos ižvalgos [Julius Juzeliūnas: Panorama of Life, Activity, and Creativity], Vilnius, 2015, pp. 109-110.

\section{Archival sources}

Design, 1960. Design for the Lithuanian SSR Composers' Association houses and concert hall in Vilnius, 1960, Vilnius Regional State Archives (VRVA), f. 1036, ap. 11 , b. 228 , I. 2.

Design, 1970. Design for the $3^{\text {rd }}$ microrayon of Lazdynai residential rayon, 1970, Vilnius Regional State Archives (VRVA), f. 1036, ap. 11, b. 669.

Files, 1961. Files and characteristics of persons applying for foreign visits, 1961, Lithuanian Archive of Literature and Arts (LLMA), f. 87, ap. 1, b. 351, p. 57, 86, 94, 98, 95, 106.

Materials, 1959a. Materials on the visits of Soviet architects to foreign countries (plans, programs, and lists), 1959, RGALI, f. 674, op. 3, d. 1598.

Materials, 1959b. Materials on the visits of Soviet architects to foreign countries (plans, programs, and lists), 1960, RGALI, f. 674, op. 3, d. 1625.

Program, 1959. Programme of the visit of Soviet architects to Finland, June 919 1959, personal collection of the architect Vytautas Čekanauskas.

Program, 1964. Programme of the trip to Finland, Tour No. 1, 1964, personal collection of the architect Vytautas Brédikis.

Report, 1956. Report of the delegation of Soviet architects on studying foreign construction experience, Russian State Archive for Literature and Arts (RGALI), f. 674 , op. 3 , d. 1356 , p. 8.

Report, 1957. Report of the Gosstroi delegation on the visit to Scandinavian countries, No. 497, October 2, Lithuanian Archive of Arts and Literature (LLMA), f. 87 , ap. 1 , b. 227, pp. 2-28.

\section{$\underline{\text { Interviews }}$}

Brèdikis, 2011. Author's interview with architect Vytautas Brèdikis, Vilnius, August 2, 2011, personal archive.

Čekanauskas, 2006. Author's interview with architect Vytautas Edmundas Čekanauskas, Vilnius, December 11, 2006, personal archive. 
Architectural Research in Finland, Vol. 4, No. 1 (2020)

Mazūras, 2011. Author's interview with Česlovas Mazūras, Vilnius, December 9 , 2011, personal archive.

Šeibokas, 2010. Gabrielè Nemeikaitè's interview with architect Justinas Šeibokas, Vilnius, May 18, 2010, personal archive. 